FACTA UNIVERSITATIS

Series: Teaching, Learning and Teacher Education Vol. 3, No 2, 2019, pp. 171 - 182

https://doi.org/10.22190/FUTLTE1902171M

Review article

\title{
DISCIPLINARY AND THEORETICAL APPROACH TO THE PRO-ENVIRONMENTAL ORIENTATION OF THE EDUCATION FOR SUSTAINABLE DEVELOPMENT
}

UDC 371.3: 502/504; 316.334.5; 373:502/504

\section{Ljiljana Mitić, Danijela Zdravković, Srboljub Dimitrijević}

\author{
Pedagogical Faculty in Vranje, University of Niš, Serbia
}

\begin{abstract}
This paper examines the relationship and scope of the convergence of environmentally oriented disciplines (sociology and pedagogy), sub disciplines theoretical approaches (socio-environmental theory and ecological systems theory) which focus on the integration of contemporary society, individual and nature, all with the goal of sustainable development and common prosperity. In the process of globalization, man is largely forced to be flexible and to adapt to the mechanisms of the market economy and to adopt the principles of any type of diversity. The connection between environmental values, knowledge and experiences is the central idea of education for sustainable development. The main paradigm of environmental orientation requires the redefinition of the educational goals, in order to balance the changes to the "identitary" culture and value matrices of general social importance during the sustainable development process. It is clear that by defining the desirable environmental values and action competences that are pro-environmental, it would result in the optimum model of sustainable development within the education system, which ensures local and global development and progress. For these reasons, in addition to formal and university education, the education for sustainable development is achieved by self-education, non-formal and informal education. We conclude that the development and transfer of value matrices in the implicit curriculum which are based on the interactive encouragement of environmental sensitivity and social experiences in immediate communication in the classroom and school, can affect the adoption of ethical and environmental sustainability standards, as well as action competencies to address many important social issues.
\end{abstract}

Key words: environmental values, education, social ecology, ecological theory, sustainable development

Received July 8, 2019/Accepted October 21, 2019

Corresponding author: Ljiljana Mitić

Pedagogical Faculty in Vranje, University of Niš, Partizanska 14, 75000 Vranje, Serbia

Phone: +381 17422962 •E-mail: ljiljanam@pfvr.ni.ac.rs 


\section{INTRODUCTION}

The contemporary, highly globalized world is conditioned by the economy of modern society and success. "The society which we live in today is largely affected by globalization, and in a way, by the accelerated integration of all aspects of human activity" (Zdravković and Stojadinović, 2010, 252). The post-modern consumer society intensifies the dynamics of living and working, where the individual adjusts to the consumer mechanisms, exploiting the majority of available social and natural resources. At the end of the second decade of the third millennium, in order to keep up with the continuity of the existing order, the main paradigm of technocracy and consumer mentality imposed a dehumanized lifestyle on the modern man.

Modern society is characterized by "a high degree of fluidity and uncertainty: while the stable communities which relied on normative expectations and patterns had a certain way of life, today's societies have a lifestyle that is freely chosen, continuously (re)structured and which serves as the basis for educating equally fluid and neolocal social groups (Chaney, 1996, cited by: Spasić, 2004, 16). The new living conditions lead to an imbalance between the needs and reality in every aspect of social life. The modern man is confused by the roles and needs, he is in conflict with himself, but also with the consequences of social actions, both in the natural and the social environment. Therefore, the reasons for these deconstructions and transformations come from the fact that the ideology of the humanistic dimension of social development is gone and that all this results in blocking the selfawareness development. When blocking this complex and multilayered social process characterized by the crisis of identity and the crisis of self-awareness, the only impulses of social development are contained in satisfying the need for self-sustainability: securing material existence and privileged living standards.

Some of the significant scientific sociological sub disciplines which study the social development, contradictory relations among nature, society and culture, as well as the education system are social ecology, sociology of development, sociology of curriculum, etc.

Nature is the broadest aspect of modern society, and the relationships between individuals, social groups, social communities and nature are turbulent, uncertain and insecure. Synchronizing the dynamics of the relationship between the natural and social environment can be primarily achieved by generating entrepreneurial innovations, and also by changing the structure and dynamics of professional life and personal, everyday life. These processes are controlled by the use of scientific and technical/technological inventions as part of the fourth industrial revolution. Scientific and technological innovations, as well as global integration during a steady global population growth, cause and direct global social movements. Currently, one of the leading environmental issues is the population explosion in developing countries, because overpopulation is a "warning and a call" for the physical relocation of the population during the postmodern "struggle for existence", which is socially challenged and motivated. Although many scientific discourses on the blocked social development are contradictory to each other, one thing is certain - this century focuses on social activities, which may have been characteristic of the 19th century. Because, this century will be more of a century of the individual, market and economy, and less of a century of the masses, country and politics; it will resemble the century where people believed more in themselves and expected more from themselves, and less the century in which people believed in "gods beyond themselves" and asked these "gods" to provide solutions (Vukotić, 2012). There is also a dilemma why Europe is becoming a demographically empty continent full of history, 
with huge needs for population imports, and does this history of the mechanical movement of the population from Asia to Europe repeat itself and resemble the period before Jesus Christ? Or is this, perhaps, the development of a universal human strategy for the preservation of the balance between man and nature, that is, a concept of life that allows the survival of only those species and resources which are highly conscientious and humane.

\section{ON THE NEED TO ENCOURAGE ENVIRONMENTAL SENSITIVITY}

The relationship between man and nature is defined by the system of values towards the environment and the relationship towards oneself, to other people, to the country and the social environment. The most direct influence that nature has on human beings is by satisfying man's needs, which is partly achieved thanks to the natural resources. The question is whether the most conscientious educated people should be the ones to determine what the relationship towards nature should look like and provide a perspective and strategy for future generations, who will be more environmentally focused?

During the process of globalization, the natural environment has been used all over the world for inhumane purposes of increasing the profits by multinational corporations, all in the service of satisfying the above-mentioned needs. "High degree of integration of the world often results in the consequences that globalization has on everyday life" (Zdravković and Stojadinović, 2010, 253).

We are witnessing many natural and social disasters, social inequalities, civil conflicts, mechanical movement of population, terrorist attacks and the general uncertainty and risk which are all characteristics of the contemporary society. It is precisely because of this exploitative and egotistic relationship that people have toward natural resources that nature fights back the modern man. What will develop in man during his lifetime mostly depends on genetics, but also on the influence family has which shapes the character of the person, and since the family is partly dependent on society and its general climate, it is then certain that psychological and sociological factors largely affect the final ethical features of man (Jerotić, 2017, 8). It would be desirable for an individual to strive to uphold the values of the common good, to be sensitive to diversity, because as academician Vladeta Jerotic, the visionary of social change, said "good and evil go hand in hand". In this sense, the basis for the "pro-environmental contemporary society" is actually being aware of oneself, of one's abilities, needs, interests, especially of one' creativity, in order to develop self-awareness for the well-being of nature and society. The proactivity of the main participants in the educational process (pupils, students, teachers, professors) is also reflected in the need to define the idea of the value of environmental sensitivity, which is qualitatively determined as a virtue resulting from humanistic education. Environmental dimension of education is particularly important and it is seen as an essential life skill when it comes to transferring global values and virtues.

Let us remind ourselves that in the last decades of the past millennium, the study of global social development in the context of environmental issues was based on the knowledge that not only society is a part of nature, but that nature is also an important factor in society. Furthermore, we can conclude that nature can supply us with ethical principles, and that a balanced ecosystem promotes diversity and interaction and alleviates the influence of any type of dominance. Therefore, it is entirely justified that the Sociology of Development is recognized as the reflexive scientific discipline, which discusses the 
dangers and possibilities of applying the generated scientific discoveries, both because of the critical reflection on knowledge in general, including environmental knowledge, and because of the fact that this knowledge originated from certain national and institutional ideologies, interest groups, political and economic structures, or scientific researchers.

Environmental sensitivity is an action competence that stands in opposition to productivism as life philosophy. Nowadays, a person is highly valued if he or she possesses technical and operational knowledge, due to which education has become a type of "goods or product". Education, as a product or commodity in the vortex of economic dynamics and chase for success, has deviated from rational thinking and critical reasoning. In this sense, the dominant efforts were directed towards the fundamental destruction of the concept of humanistic education in favor of the development of instrumentalist (power concept) thinking, and we are also adding the encouragement of social sensitivity towards environmental values and sustainable development.

In this case, it seems that it is not enough to only observe the nature and consequences of environmental crises. Rihta (1972) spoke about the need to raise consciousness and awareness of the dangers to human survival, which is the result of the accelerated development and disturbance of environmental balance. Therefore, further social development requires deeper rationality in creating the relationship between man, nature and cultures through the education of future generations.

\section{The Relationship BetweEn EduCATION, Culture AND SOCIAL DEVElOPMENT}

Marković (2002) studied the relationship between education and social development, and he started from the universal conceptual definition of development, without the emphasis on certain ethical and other social specifics. The concept of development has been, especially in sociology, discussed about from various perspectives and based on different theoretical approaches in order to identify the laws of social development. "Development is most often characterized by the overcoming of insufficiency and the removal of obstacles (and limitations) which is seen as achieving certain social goals, which people aim at in order to have better living conditions (...) development is seen as a complex and multilayered process that contains many components and reflects the cultural and moral goals embedded in the history, heritage and tradition of a society whose development is being analyzed" (pp.4).

Social development is a complex, polyvalent multi-dimensional process, which contains the totality of factors (objective and subjective, internal and external) which further determine its range and quality.

According to Mitrović (2012), the general paradigm of social development emphasizes the dialectics of the unity of opposites - on the one hand, the process of one's individualization, and on the other hand, their connection (socialization) in broader and social terms. This paradigm starts from the autonomy of parts as the precondition for the democratic unity of the whole.

When determining the relationship between education and social development in the context of sustainability, it is necessary to redefine the concept of social development that will be used within the education concept, with the goal of developing environmental awareness, and to allow for a realistic view of the consequences and provide a long-term sustainability perspective. Mitrović concludes that the sublimation of the concept of social development with the new integral humanist concept promotes some dimensions of 
the concept of integral human development at the center of which are sustainable development, people's right to exist, world peace, well-being and happiness.

The crucial developmental resources contained in education, analyzed from the aspect of education and culture, also require a critical review of the relationship between institutionalized forms of education organization and culture. (Marković, 2002, 19). It is necessary for the social institutions of culture, which are engaged in education, to be open to providing services in meeting the emancipatory needs of the contemporary society.

The precondition for sustainable development is to accept moral standards in understanding good and evil, as well as in understanding moral behavior, which is a part of cultural globalization. Therefore, the concept of global ethics has originated, which is defined as a system of common values, such as: human rights and responsibilities, democracy and civil society, protecting minority rights, peaceful conflict resolution, generational and intergenerational responsibility to conserve and preserve natural resources for the benefit of present and future generations (Pastuović, 1999).

On the one hand, contemporary social development on the global level is mirrored in the dichotomy of education and science as key development resources.

From the standpoint of the sociology of development, it is necessary to emphasize the importance to study the role of education during the process of globalization, especially the so-called humanistic education, both from the aspect of the development of an individual, and the possible rational and humane social development of the community and beyond. Humanistic pedagogy focuses on the creation of a complete personality, contrary to Marcuse's one-dimensional man; it also focuses on higher-order values, and the maximum achievement of one's potentials, abilities, needs, interests, and especially creativity. The beginnings of humanism in the history of human civilization are linked to Aristotle and Confucius, while the main sources of inspiration for the modern humanistic theories of education were the representatives of the 19th century existentialism (Milutinović, 2008).

An adequate approach to social development and education for sustainable development requires understanding and acceptance of environmental laws. Education for sustainable development should be included in all social processes, and the factors affecting the education for sustainable development are family, preschool institutions, schools, universities, mass media, social and cultural organizations, companies, and international and national experiences as examples of good practice.

\section{CONTRIBUTION TO THE SHAPING OF ECO-SENSIBILITY: FROM THE SOCIO-ENVIRONMENTAL DIMENSION OF EDUCATION TO THE SOCIOLOGY OF THE CURRICULUM}

The development of the socio-environmental approach has also been affected and guided by the following circumstances in natural and social sciences: 1) disciplinary convergence of natural and social (human) sciences due to the increased complexity of the research subject; 2) the use of the term system in natural and social sciences; 3) the emergence of the environmental crisis and a shift in finding causes and solutions from the biological to the social aspects; 4) the shift of environmental and social problems from a local to a global level, so ecology is seen as global ecology (Glavač, 2011 cited by Cifrić, 2012). As a discipline, social ecology can be seen as the link between natural and social sciences. 
Contemporary challenges worldwide indicate that the individual and modern society are essential and integral elements of the global ecosystem, which is why it is impermissible for the curricula to exclude the knowledge of social sciences in dealing with environmental issues. Educational policy is a strategic stronghold and a key issue of the country policy which is supposed to reflect the main vision regarding the contents of the educational process, the profile of social and economic organizations, and the position of the country within the international division of labor (Zdravković, 2010, 181). The concept of global education is the concept which approaches the third millennium education from a dynamic point of view, that is, it believes that education is continuously and exponentially developed under the influence of three factors:1) changes in scientific and technological knowledge, which requires constant changes and leads to an increase in the intensity of education, 2) ongoing changes in the world economy, which will further require a flexible, efficient and easily accessible system of retraining, knowledge innovation and improvement, etc., 3) dramatic cultural changes from the perspective of the young generation (Zdravković, 2010, 181). Therefore, it would be completely justified for the process of socialization of children, pupils and students, as well as their academic success in a global social context, to be tracked via a formal, real and explicit education program, which would be aligned with the concepts such as socio-environmental paradigm, ecosophy or ecophilosophy, ecopedagogy and environmental education. Socio-environmental paradigm is the model used to study the unity of society, culture and nature, with a special emphasis on socioenvironmental balance, changes in the values of a society, development issues, attitude towards life, educational process... Ecosophy is defined as a life philosophy that encourages the equilibrium between humans and their natural environment, as well as a change in people's consciousness in relation to personal responsibility, whereby society values are the basis of ethical criteria and moral evaluation (Cifrić, 2012, 120). According to Cifric (2012) ecopedagogy supports and encourages the need for radical changes to the basic notions of society, discusses the role of education and the relationship between man and nature. Due to the environmental and educational crisis, there have emerged various connections between social sciences and ecology, including different approaches to the scientific interpretation of environmental issues, as well as the need to emphasize the fact that social demands for learning at school, although often hidden, are very important.

A relatively new sub-discipline of the sociology of education is the sociology of the curriculum, originated in the 1970s in the United Kingdom, which in addition to the formal and real curriculum insists on making a distinction between the explicit, real and true curriculum, and the implicit, informal and hidden curriculum. Interactionist paradigm and ethno methodological approach, as well as ethno methodological research of curricula, have shown that communication, behavior and personal experiences in the classroom and school, both in students and teachers, are important for intensifying sensitivity towards environmental issues, without these being a part of the explicit curriculum. The following question arises: is the hidden curriculum and to what extent involved in shaping the environmental education for sustainable development? In answering this question, we abandon the framework of environmental, theoretical and methodological approaches and embrace the view that if the impact of globalization and global education on the curriculum of a country is high, the idiosyncrasy of its curriculum and educational system is weakened (Georgievski, 2007, 551). We are witnessing contradictions which shape the profile of a new active citizen in the Balkans, who is pro-environmental and ready to quickly adapt to the current social situation. The skills and abilities necessary for the life and work of future 
generations in a sustainable development society should be observed from the perspective of action competencies.

When studying and analyzing the formal (national), real and hidden curriculum, it is necessary to use different theoretical approaches because they form the basis of the education for sustainable development. In order to further emphasize the importance of the connection between the society and science, it is important for people to understand the scientific way of thinking and to take part in these efforts in order for some serious social issues to be solved. This also implies the interaction between educational resources, such as the postulates of ecologization aligned with the new educational paradigm for sustainable development: social ecology and the ecology human development, and the individuals who are committed to change people's value system - in favor of action and awareness for environment protection, since such people are the creators of a sustainable society. Only in this way can it be possible to obtain more complete knowledge of how and to what extent these different forms of curricula affect the socialization process in the context of pro-environmental orientation, as well as how they affect the formation of their identities and social promotion (Georgievski, 2007, 551). In addition to redefining goals and objectives of socio-environmental learning and environmental education within the formal curriculum, these theoretical approaches could positively affect the formation and strengthening of self-competences and social competences as the outcomes of discourses on sustainable development.

\section{PRO-ENVIRONMENTAL ORIENTATION IN THEORETICAL APPROACHES TO SUSTAINABLE DEVELOPMENT}

Solving the important issues of contemporary civilization, including the environmental issues can only be possible by implementing the concept of sustainable development. The principles of sustainable development form the basis of sustainable development, while the needs for non-material (spiritual) values important to motivate the advocacy groups, also known as special interest groups, to solve environmental issues and the global crisis will be met only depending on the adherence to certain principles of sustainable development in the future. Theoretical and practical contributions to the education process and the education for sustainable development are also very important. These scientific contributions and their social significance have been presented at numerous summits and conferences: the conference in Veldhoven (1990), called Learning and Development Coordination, the conference in Bergen (1990) where the declaration Our Common Future was issued, as well as the world's biggest conference dedicated to the environment and sustainable development held in Rio de Janeiro (1992), where the main topic was Environment and Development. The official document developed during this conference was "Agenda 21", which is an expression of a global consensus and political endeavor for cooperation in the field of social development and environmental protection. Chapter 36 deals with the functions of the school education system, professional development and the promotion of environmental awareness, through the following program areas: the reorientation of education towards sustainable development, raising public awareness and the improvement of training. It is well-known that in defining sustainable development, many authors refer to the ethical, technical and historical context.

Relevant to our analysis is the ethical context of the definition which can be seen in the third principle of the Rio Declaration (out of a total of twenty-seven principles of 
sustainable development) - The right to development must be fulfilled so as to equitably meet developmental and environmental needs of present and future generations (UN, Rio de Janeiro, 1992).

Through the United Nations system, the Republic of Serbia has committed to comply with and implement a range of education-related measures (Miltojević, Nikolić, 2006).

These measures also include those related to environmental education for sustainable development. This means that our country, like everyone else in Europe, must comply with the prescribed norms and regulations.

This section of the paper presents the analysis of the theoretical approaches with the emphasis on their pro-environmental orientation and their readiness to use experience and science to identify the relevant postulates which would motivate individuals and social groups to acquire habits and knowledge that are supposed to lead to the improvement of the quality of social life without disturbing natural equilibrium. Moreover, this paper made an attempt to provide an answer how the education process affects the perception of ethical and environmental values in terms of people's affiliation to nature and society, their interaction, and the way how people are taught from the early childhood how to deal with the distribution of power and resources in times of rapid growth, in order for them as future mature people to act in accordance with a preferred set of moral and environmental values fostered by culture and education. By embracing the recent pedagogical imperative, which seeks to re-evaluate the education system of values, and in favor of environmental values seen as a virtue, the second part of the paper presents the conclusions obtained by the analysis of the theoretical approaches examined (Social Ecology and Bronfenbrenner's Ecological Systems Theory). From the general idea to the philosophy of life, from the education for sustainable development to a lifestyle, all in order to encourage new research questions about the actual image and the current position of environmental values within the education system in the Republic of Serbia. Bearing in mind the previous attempts to conceptualize education for sustainable society using the analyses of theoretical approaches such as Ecological Ethics, Social Ecology, Social Constructivism and Bronfenbrenner's Ecological Systems Theory in the paper titled "Humanistic and ecological dimension in the theoretical approaches to the education for sustainable society" (Marić and Jurišin, 2018, 72), we conclude that the development and transfer of environmental values is achieved through the holistic understanding of the global society, and that the foundations of education for sustainable development are contained in socio-ecological and ecological theory.

\subsection{Social ecology}

The idea of social ecology in education originated not that long ago, in 1866, when German biologist Ernst Haeckel expanded the domain of ecology outside the biological aspect and for the first time used the term ecology by combining two Greek words oikos and logos which are translated to home and science. Nowadays, we can see the expansion of ecology at universities, and a number of scientific disciplines related to this new scientific field are being developed. It is precisely in the process of disciplinary development that ecology is proven to be not only a natural but also a human science. Rapid social changes have also expanded the field of study of this scientific discipline; thus, the environmental issues are now analyzed from the social aspect and at the global level. Therefore, in addition to biological, medical, human and political ecology, there have been more and more discussion about social ecology (Mišković, 2013). Ivan Cifrić (2012) defines social ecology 
as a sociologically and ecologically oriented discipline that goes beyond the sociological and ecological limitations of subjects and methods. The Chicago school had a significant impact on its development and it was this school that coined the term human ecology. E.R. Park and E.W. Burges (1921) define the social ecology as an ecological way of examining human society, with a particular emphasis on the problem of planning large cities. Social sciences analyze and emphasize the social consequences of the coexistence between man and the environment. Ecology includes a great number of disciplines that analyze the mutual relationship between man and the environment from various perspectives. "Ecology is related to demography, ethnography, rural and urban sociology and the sociology of community by studying the relationship between demographic structures, climatic and geographic factors, technologies and social organization of a society. In a narrower sense, ecology includes the research of natural resources which affect man's production efforts, rural and urban circumstances, cultural development, etc. (Cifrić,1989, 300).

Perhaps the most important ideological, theoretical and empirical development path of the socio-ecological thought that refers to urban sociology is known as human ecology. In a broad sense, social ecology arises from the need to connect ecological and social issues. A long time ago, in ancient times, it became clear that the relationship between the environment and people is complex and very important. The scientific definition of social ecology was developed in the mid-19th century, especially with regard to Engels's observations on the living conditions and the position of the working class in heavily populated English industrial cities. The theoretical discussion about the connection between the natural and social factors of the organization and functioning of human communities started only in the second half of the 20th century. This delay can be explained by the disturbed balance between technical and technological components, natural potentials and social organization during the period characterized by great demands for growth and development, and it occurred in all types of human settlements, both rural and urban. Nevertheless, many human communities have always been the most representative indicators of social disorganization arising from the inability to meet high and non-compliant developmental demands.

It should be emphasized that social ecology is interested in at least three levels of interconnection between the environment and human communities:

1. Global level - global processes disrupting the balance between man and environment and highlighting social phenomena as well as their consequences;

2. Level of cultural transition - the effect of natural and acquired factors on the organization and functioning of human communities;

3. Regional level - imbalance at the level of settlements; (Pušić, 2002, 56-57).

With regard to population, technology, technical aspects and organization the cities have grown and expanded exponentially world-wide over the past hundred years. All this provoked a kind of rebellion of nature, which is less and less in the state of passive suffering. It can be said that the level of ecological imbalance, the growth of the cities and the degree of complexity of social disorganization are interconnected. This social phenomenon of overpopulation corresponds to the ruling paradigm of sustainable society, globally, and we are witnessing the current mechanical movements of the population from one continent to the other, in order to ensure a balance in social development without serious consequences in the future. 


\subsection{The ecological dimension of social development}

The ecological approach to the study of human development requires a change in the conventional view of the preferred relationship between science and public policy. Development is defined as the awareness-raising about ecology, people's relationship with it, as well as the growing ability of a person to discover and change its characteristics (Bronfenbrenner, 1997, 18-19). This definition provided by Bronfenbrenner shows us that he was influenced by Lev Vygotsky, in particular his emphasis on close relationships and isomorphism between mental structure, person, and situation. The proposed concept also relies heavily on the ideas presented by Piaget, in particular those presented in Piaget's study the construction of reality in the child (1954).

Bronfenbrenner's ecological theory, the ecology of human development, tends to embrace transdisciplinary and convergent connection between the biological, psychological and social scientific disciplines based on their effect on the development of an individual in a society. We might ask ourselves what makes the ecology of human development different from, on the one hand social psychology, and on the other hand, from sociology and social anthropology. In general, the answer can be found in the phenomenon of development within context (Bronfenbrenner, 1997, 18-19).

At its core, ecology deals with the ongoing compromise between the evolving man and the environment, and this is what separates it from the prevailing approaches to the study of human development (Bronfenbrenner, 1997, 23).

In order to overcome the contemporary ecological crisis, modern man should adopt a new holistic approach to sustainable, ecological development, where all developmental resources will be integrated and respected, and which will equally deal with ecological and social problems. Education is a powerful development resource that affects the resolution of numerous global social issues and the development of different relationships on the relationship between the developed and the developing countries, as well as of the different relationships between modern society and nature.

\section{INSTEAD OF A CONCLUSION}

As suggested by the modern trends in education, the conceptualization of ecological and methodological approaches to sustainable development can be supported by certain sociological and pedagogical viewpoints and scientific studies focused on sustainable development. There is a contradiction between the growing political, social and economic challenges, needs, issues, as well as the digital achievements of the fourth industrial revolution, and the tradition which ensured security, but not sustainability. Therefore, it is even more difficult to carry out the reformation of education regarding the improvement of the quality of life on the economic and social level without disturbing the balance in nature. This inconsistency is present even today, and there have been criticisms and warnings by the sociologists, demographers, pedagogues, ecologists, ecological movements, etc. both at the normative and the declarative level. The dominant factor in postmodern society consumerism, has suppressed ethical and ecological criteria and values that the system of institutional education had been based on for a long time. Education experts believe that young generations must be systematically and competently educated, and warn the public that the institutional education system is the most important factor in creating our own future, as well as the quality of life of people and their communities. "It is particularly 
important to teach children how to communicate in a democratic and humane way, as well as how to build self-esteem and a positive self-image" (Zdravković and Stojadinović, 2011, 514). Continuous formal and informal education, together with the proper learning materials, knowledge and activities are required in order to solve the existential problems in contemporary society, and in order to ensure its sustainability in terms of balancing democratization and humanization. In connection with this, Federico Major concludes that in all responsible societies these initiatives come "from the top" (...) "from all the factors affecting a balanced development, the most important is intelligence. While the rulers do not see this as important, statesmen always do." (Marković, 2002, 2).

Education for sustainable development is multidisciplinary, with the emphasis on timely social response and people's creativity which should help mitigate the consequences of the ecological crisis. Pro-ecological education for sustainable development is the goal, the need and the developmental resource of people investing in their future. Universities, science and education institutions play a significant and indispensable role in studying the developmental ecological paradigms, "green alternatives" and sustainable development projects for the future. There is a great responsibility and according to F. Mayor, "there are limits to growth, but there are no limits to learning".

\section{REFERENCES}

Georgievski, P. (2007). Sociologija nastavnog programa. U: Sociološki rečnik/prir. Aljoša Mimica i Marija Bogdanović. Beograd: ZUNS, 549-551.

Glavač, V. (2001). Uvod u globalnu ekologiju. Zagreb: Hrvatska sveučilišna naklada; Ministarstvo zaštite okoliša i prostornog uređenja; Pučko otvoreno učilište.

Đukanović, M. (1991). Ekološki Izazov. Beograd: ELIT.

Đukanović, M. (1996). Životna sredina i održivi razvoj, Beograd: ELIT.

Zdravković, D. (2010). Global education: education for peace and less violence. Didactica Slovenica: Pedagoška obzorja. Letnik 25 /2.

Zdravković, V., Stojadinović, A. (2010). Muzička tradicija i nacionalno vaspitanje u globalizacijskom kontekstu. U: Mogućnost nacionalnog vaspitanja u vreme globalizacije. Vranje: Učiteljski fakultet $\mathrm{u}$ Vranju, 252-264.

Zdravković, V., Stojadinović, A. (2011). Muzičkom igrom do humanih odnosa u savremenom društvu. U: Vaspitanje za humane odnose problemi i perspective. Niš: Filozofski fakultet, 514-523.

Кнежевић, М. (2008). Етика епских народних песама као модел у васпитно-образовном раду. У: Етичка димензија образовања. Јагодина: Педагошки факултет, 123-131.

Jerotić, V. (2017). Dobro i zlo trče zajedno. Beograd: Zadužbina Vladete Jerotića.

Major, F. (1991). Sutra je uvek kasno. Beograd: Jugoslovenska revija.

Marić Jurišin, S. (2018). Humanističko-ekološka dimenzija u teorijskim polazištima vaspitanja i obrazovanja za održivo društvo. Pedagoška stvarnost, 1, 62-75.

Marković, D. Ž.(2002). Savremenost i obrazovanje. Beograd: Prosveta.

Mitrović, M. (1996). Savremeno društvo. Beograd: Institut za političke studije.

Mitrović, Lj. (2012). Univerzitet i društvene promene. Sociološki ogledi. Vranje: Učiteljski fakultet u Vranju.

Milutinović, J. (2008). Ciljevi obrazovanja i učenja u svetlu dominantnih teorija vaspitanja 20. veka. Novi Sad: Savez pedagoških društava Vojvodine.

Nikolić, V. (2003). Obrazovanje i zaštita životne sredine. Beograd: Zadužbina Andrejević.

Pastuović, N. (1999). Edukologija: Integrativna znanost o sustavu cjeloživotnog obrazovanja i odgoja. Zagreb: Znamen.

Pušić, Lj. (2001). Održivi grad, ka jednoj sociologiji okuženja. Beograd: Srboštampa.

Pečujlić, M. (1991). Savremena sociologija, Službeni list SFRJ, Beograd.

Radulović, J. i drugi. (1997). Koncept održivog razvoja. Beograd: Savezno ministarstvo za razvoj, nauku i životnu sredinu.

Saks, D. Dž. (2014). Doba održivog razvoja, Beograd: CIRSD.

Supek, R. (1973). Ova jedina zemlja. Zagreb: Naprijed. 
Spasić, I. (2004). Sociologija svakodnevnog života. Beograd: ZUNS.

Cifrić, I. (1989). Socijalna ekologija. Zagreb: Globus.

Cifrić, I. (2012). Leksikon socijalne ekologije. Zagreb: Školska knjiga.

Cooper, C. (1981). Economic Evaluation and the Environment. Hodder and Stoughton: London.

\section{DISCIPLINARNO-TEORIJSKI PRISTUP U PROEKOLOŠKOJ ORIJENTISANOSTI OBRAZOVANJA ZA ODRŽIVI RAZVOJ}

Autori u ovom radu ispituju odnos $i$ domete uzajamnog približavanja ekološki orijentisanih disciplinarnih (sociologija i pedagogija), poddisciplinarnih (sociologija razvoja, socijalna ekologija, humana ekologija, humana pedagogija, sociologija nastavnih programa), teorijskih (socio-ekološka teorija i ekološka teorija) pristupa, sadržanih u integrisanju savremenog društva, pojedinca i prirode, a sve u cilju odživog razvoja $i$ zajedničkog blagostanja. Prožimanje ekoloških vrednosti, znanja $i$ doživljaja je centralna ideja obrazovanja za održivi razvoj. Vladajuća paradigma ekološke orijentisanosti zahteva redefinisanje ciljeva obrazovnog sistema, u kontekstu uravnotežavanja promena "identitarne" kulture $i$ vrednosne matrice opšte društvene važnosti u uslovima održivog razvoja. Jasno je, da se sa definisanjem poželjnih ekoloških vrednosti i akcionih kompetencija koje su proekološke orijentisane, u obrazovanom sistemu konstruiše optimalni model održivog razvoja, koji obezbeđuje lokalni i planetarni razvoj i napredak. Iz tih razloga, osim formalnog i univerzitetskog obrazovanja, obrazovanje za održivi razvoj se sprovodi $i$ samoobrazovanjem, neformalnim $i$ informalnim obrazovanjem. U radu pokušavamo, da u kontekstu savremenih obrazovnih tendencija, izdvojimo mesto i ulogu eksplicitnog i implicitnog nastavnog programa vaspitno-obrazovnog sistema na podsticanju emocionalnih doživljaja i socijalnih iskustava $i$ usvajanju etičkih $i$ ekoloških normi održivosti. Zaključujemo, da razvijanje i prenošenje vrednosnih matrica u implicitnom kurikulumu, koje počivaju na interaktivnom podsticanju ekološkog senzibiliteta i socijalnih iskustava $u$ neposrednoj kominikaciji u učionici $i$ školi, mogu doprineti usvajanju etičkih $i$ ekoloških normi održivosti, kao i akcionih kompetencija za rešavanje mnogih važnih društvenih problema današnjice.

Ključne reči: ekološke vrednosti, obrazovanje, socijalna ekologija, ekološka teorija, održivi razvoj 